\title{
PENANGANAN PERKARA ANAK DALAM PERSPEKTIF JAKSA PENUNTUT UMUM
}

\author{
Betania Fransiska Sitanggang ${ }^{1 *}$, Irma Cahyaningtyas ${ }^{2}$ \\ ${ }^{1}$ Fakultas Hukum, Universitas Atma J aya Yogyakarta \\ ${ }^{2}$ Fakultas Hukum, Universitas Diponegoro \\ Purplesitanggang@yahoo.co.id
}

\begin{abstract}
Special authority is provided by Law No. 11 of 2012 concerning the J uvenile J ustice System to the Attorney General's Office of the Republic of Indonesia is a new mandate for all public prosecutors in Indonesia, especially in the City of Semarang. This authority is seen from the case handling of 58 (fifty eight). The large number of cases is due to the complexity that arises from crimes committed by children, both the influence of the child's social environment or the lack of parental supervision. This study uses an empirical juridical method with a sociolegal approach. The first research results show that during 2016-2018 the public prosecutor has succeeded in resolving the case of children with diversion of 2 (two) cases, while the case which was unsuccessful was diversified due to obstacles from parents / guardians of victims or perpetrators. Whereas the results of the second research show that the diversion model that has been carried out so far is time to shift by using the family group conference model. By using the family group conference settlement model, the involvement of parents / guardians, victims / perpetrators' families, and the local community will look objective in resolving child crime cases.
\end{abstract}

\section{Keywords: Public Prosecutor; Child; Semarang city.}

\begin{abstract}
ABSTRAK
Adanya kewenangan khusus oleh Undang-Undang No. 11 Tahun 2012 Tentang Sistem Peradilan Anak kepada Kejaksaan Republik Indonesia merupakan amanah baru bagi seluruh jaksa penuntut umum di Indonesia khususnya di Kota Semarang. Kewenangan ini dilihat dari penanganan perkara sebanyak 58 (lima puluh delapan). Banyaknya kasus tersebut diakibatkan kompleksitas yang muncul oleh kejahatan yang dilakukan anak, baik itu pengaruh lingkungan pergaulan anak ataupun kurangnya pengawasan orang tua. Penelitian ini menggunakan metode yuridis empiris dengan pendekatan sociolegal. Hasil Penelitian pertama menunjukan bahwa selama tahun 2016-2018 jaksa penuntut umum telah berhasil menyelesaiakn perkara anak dengan diversi sebanyak 2 (dua) perkara, sedangkan perkara yang tidak berhasil dilakukan diversi disebabkan adanya hambatan dari orang tua/wali korban atau pelaku. Sedangkan hasil penelitian kedua menunjukan bahwa model diversi yang selama ini dilakukan sudah saatnya bergeser dengan menggunakan model family group conference. Dengan menggunakan model penyelesaian family group conference maka keterlibatan orang tua/wali, keluarga korban/pelaku, dan masyarakat lingkungan setempat akan terlihat objektif dalam menyelesaikan kasus kejahatan anak.
\end{abstract}

Kata Kunci: J aksa Penuntut Umum; Anak; Kota Semarang.

\footnotetext{
${ }^{*}$ Corresponding Author
} 


\section{A. PENDAHULUAN}

Munculnya Undang-undang mengenai SPPA menghadirkan formula-formula baru dalam sistem peradilan anak, salah satunya terkait dengan penanganan terhadap anak. Formula dalam penanganan ini mengedepankan prinsip "win - win solution" atau disebut diversi. Pasal 1 ayat (7) UU No. 11 Tahun 2012 Tentang Sistem Peradilan Anak menyebutkan bahwa Diversi merupakan pengalihan penyelesaian perkara Anak dari proses peradilan pidana ke proses di luar peradilan pidana. Tujuan adanya diversi tersebut agar mencapai perdamaian antara korban dan Anak; menyelesaikan perkara Anak di luar proses peradilan; menghindarkan Anak dari perampasan kemerdekaan; mendorong masyarakat untuk berpartisipasi; dan menanamkan rasa tanggung jawab kepada Anak (Pasal 6 UUNo.11 Tahun 2012 Tentang Sistem Peradilan Anak).

Formula diversi ini akibatnya menggeser perspektif para penegak hukum kita yang semula bersifat positivis dan kaku menjadi progresif dan kompromi, hal tersebut dapat dilihat dengan adanya upaya kerjasama antara lembaga penegak hukum (Kepolisian RI,Kejaksaan Agung RI, dan Mahkamah Agung RI) yang dituangkan ke dalam nota kesepahaman bersama B-3523/E/EJP/2012 yang berkaitan dengan penerapan restorative justice. Berkaitan dengan masalah yang dibahas yaitu penanganan anak oleh kejaksaan khususnya jaksa penuntut umum.Kewenangan Jaksa dalam bidang pidana pada umumnya diatur dalam Pasal 30 Ayat (1) Undang-Undang Nomor 16 Tahun 2004 Tentang
Kejaksaan, yaitu: 1).Melakukan penuntutan; 2).Melaksanakan penetapan hakim dan putusan pengadilan yang telah memperoleh kekuatan hukum tetap; 3) Melakukan pengawasan terhadap pelaksanaan putusan pidana bersyarat, putusan pidana pengawasan, dan keputusan lepas bersyarat; 4) Melakukan penyelidikan terhadap tindak pidana tertentu berdasarkan undang-undang; 5).Melengkapi berkas perkara tertentu dan untuk itu dapat melakukan pemeriksaan tambahan sebelum dilimpahkan ke pengadilan yang dalam pelaksanaannya dikoordinasikan dengan penyidik.

Berdasarkan salah satu kewenangannya yaitu melakukan penuntutan, maka kaitannya dengan anak proses penuntutan ini terdapat kekhususan. Pasal 42 Undang-Undang No. 11 Tahun 2012 Tentang Sistem Peradilan Anak menyebutkan bahwa:

1. Penuntut Umum wajib mengupayakan Diversi paling lama 7 (tujuh) hari setelah menerima berkas perkara dari Penyidik.

2. Diversi sebagaimana dimaksud pada ayat (1) dilaksanakan paling lama 30 (tiga puluh) hari.

3. Dalam hal proses Diversi berhasil mencapai kesepakatan, Penuntut Umum menyampaikan berita acara Diversi beserta kesepakatan Diversi kepada ketua pengadilan negeri untuk dibuat penetapan.

4. Dalam hal Diversi gagal, Penuntut Umum wajib menyampaikan berita acara Diversi dan melimpahkan perkara ke pengadilan dengan melampirkan laporan hasil penelitian kemasyarakatan.

Pada proses penuntutan tersebut juga harus mempertimbangkan syarat-syarat untuk melakukan diversi terhadap anak nakal yang melakukan tindak pidana yakni (Dewi, 2011): 
1. Pelaku anak yang baru pertama kali melakukan tindak pidana

2. Umur anak relatif masih muda

3. Implementasi bentuk program-program diversi yang dikenakan pada anak mendapat persetujuan orangtua/ wali, maupun anak yang bersangkutan

4. Kejahatan yang dilakukan dapat tindak pidana yang ringan ataupun yang berat (dalam kasus tertentu)

5. Anak telah mengaku bersalah melakukan tindak pidana/kejahatan

6. Masyarakat mendukung dan tidak keberatan, atas pengalihan pemeriksaan ini

7. Jika pelaksanaan program diversi gagal, maka pelaku anak tersebut dikembalikan untuk diperiksa secara formal

Proses dan pertimbangan dalam menuntu anak juga berlaku bagi seluruh kejaksaan di manapun, khususnya bagi Kejaksaaan Negeri Kota Semarang. Berdasarkan Data yang diperoleh dari Kejaksaan Negeri Kota Semarang. Berdasarkan data yang diperoleh dari Kejaksaan Negeri Kota Semarang (kejari.semarangkota.go.id). Sejak tahun 2016-2018 Kejaksaan Negeri Kota Semarang telah menangani perkara pidana anak sebanyak 58 (lima puluh delapan) perkara dengan berbagai jenis perkara:

Tabel.1.1 Jumlah Perkara dan Jenis Pekara Pidana Anak Tahun 2016-2018

\begin{tabular}{|c|c|c|c|}
\hline Jenis Perkara & $\begin{array}{l}\text { Tahun } \\
2016\end{array}$ & $\begin{array}{l}\text { Tahun } \\
2017\end{array}$ & $\begin{array}{l}\text { Tahun } \\
2018\end{array}$ \\
\hline $\begin{array}{l}\text { Pencurian (Pasal } \\
365 \text { KUHP) }\end{array}$ & 1 & 4 & 10 \\
\hline $\begin{array}{l}\text { Pencurian (Pasal } \\
363 \text { KUHP) }\end{array}$ & 2 & 6 & 13 \\
\hline $\begin{array}{l}\text { Pencurian (Pasal } \\
362 \text { KUHP) }\end{array}$ & - & 1 & - \\
\hline $\begin{array}{l}\text { Kekerasan bersama } \\
\text { (Pasal } 170 \text { KUHP) }\end{array}$ & 1 & - & 2 \\
\hline Pembunuhan (Pasal & - & - & 4 \\
\hline
\end{tabular}

\begin{tabular}{|l|l|l|l|}
340 KUHP) & & 2 & - \\
$\begin{array}{l}\text { Narkotika (UU No. } \\
35 \text { Tahun 2009 }\end{array}$ & 1 & - & 2 \\
$\begin{array}{l}\text { Tentang Narkotika) } \\
\text { Membawa Senjatan }\end{array}$ & 1 & - & 2 \\
$\begin{array}{l}\text { Tajam (UU Darurat) } \\
\text { Pencabulan Anak } \\
\text { (UU 35 Tahun 2014 }\end{array}$ & 1 & 2 & - \\
$\begin{array}{l}\text { Tentang } \\
\text { Perlindungan Anak) }\end{array}$ & - & 1 & - \\
$\begin{array}{l}\text { Menjual Obat Keras } \\
\text { (UU NO. 36 Tahun } \\
\text { 2009 Tentang } \\
\text { Kesehatan) } \\
\text { Pemerasan (Pasal }\end{array}$ & - & 1 & - \\
$\begin{array}{l}368 \text { KUHP) } \\
\text { Penganiayaan } \\
\text { (Pasal 351 KUHP) }\end{array}$ & - & - & 1 \\
\hline
\end{tabular}

Sumber.Kejari.Semarangkota.go.id Tahun 2016-2018

Berdasarkan tabel tersebut dapat dilihat bahwa sejak tahun 2016 sampai dengan 2018 jaksa penuntut umum Kejaksaan Negeri Kota Semarang telah menuntut berbagai jenis perkara. Perkara yang paling banyak dituntut yaitu pertama perkara pencurian (Pasal 365 KUHP) di mana pada saat melakukan niat jahatnya disertakan dengan kekerasan dan mengakibatkan luka-luka berat atau kematian. Kedua, perkara pencurian (Pasal 363 KUHP di mana pada saat melakukan pencurian pelaku menggunakan cara-cara dengan merusak barang orang lain. Perkara yang paling banyak terakhir yaitu pembunuhan (Pasal $340 \mathrm{KUHP}$ ) di mana perbuatan dilakukan dengan sengaja dan dengan rencana terlebih dahulu dengan merampas nyawa orang lain.

Penanganan yang dilakukan oleh jaksa penuntut umum di Kejaksaan Negeri Kota Semarang juga menggambarkan kompleksitas dari perbuatan 
yang dilakukan oleh anak. Anak yang semulanya hanya memahami kejahatan sebagai sesuatu hal yang buruk dan dilarang, secara perlahan lahan bergeser menjadi sesuatu yang lumrah dilakukan oleh anak. Perbuatan seperti pembunuhan, pemerkosaan, pencuri, pemakai dan bahkan pengedar narkoba adalah kejahatan-kejahatan yang selama ini menjadi sesuatu yang biasa saja dilakukan oleh seorang anak.

Alasan anak menganggap kajahatan di atas sebagai sesuatu yang biasa saja atau lumrah karena didukung dengan adanya Undang-Undang Republik Indonesia Nomor 35 Tahun 2014 Tentang Perubahan Atas Undang-Undang Nomor 23 Tahun 2002 Tentang Perlindungan Anak.Bagi anak, apabila mereka melakukan kejahatan tidak perlu khawatir karena di dalam undang-undang di atas memberikan keistimewaan bagi mereka dalam pemberian sanksi.

Pada pemidanaan terhadap anak, dapat dilihat dengan adanya teori pemidanaan yang berkembang. Pertama, teori absolut/ pembalasan (retributive/vergelding). Menurut teori inipemidanaan dijatuhkan karena orang telah melakukan suatu kejahatan.Pidana diposisikan sebagai balasan atas pelanggaran hukum. Ada tindak pidana maka ada pemidanaan, dan tidak ada tindak pidana berarti tidak ada pemidanaan. Dengan demikian, setiap tindak pidana harus mendapatkan balasan yang berupa pemidanaan. Kedua, teori relatif/ tujuan (utilitarian/doeltheorieen). Teori ini memposisikan pemidanaan sebagai upaya pencegahan terhadap munculnya tindak pidana.Pemidanaan bukan ditujukan untuk memutuskan tuntutan absolut dari keadilan.Pembalasan harus dijadikan sebagai sarana untuk melindungi kepentingan masyarakat (Priyatno, 2009). Ketiga, teori gabungan (integratif).Pada dasarnya teori gabungan adalah gabungan teori absolut dan teori relatif. Gabungan kedua teori itu mengajarkan bahwa penjatuhan hukuman adalah untuk mempertahankan tata tertib hukum dalam masyarakat dan memperbaiki pribadi si penjahat (Warsito, 2018 ).

Semua teori pemidanaan yang ada pada dasarnya ditujukan untuk mencapai keadilan. Sehingga model pencapaiannya dapat dibedakan menjadi dua; yaitu model retributive justice dan model restorative justice.Model retributive justice menegakkan keadilan berdasarkan pada filsafat pembalasan, sedangkan model restorative justice berpijak pada filsafat pemulihan (Sodiqin, 2015). Dalam kasus tindak pidana anak, maka filsafat keadilan yang dianut adalah model yang keuda. Dengan demikian dalam pemidanaan kasus tindak pidana anak, menekankan pada asas restorative justice.

Penggunaan restorative justice dapat dipakai untuk menelusuri penyebab dilakukan kejahatan oleh anak.Melalui optik ilmu kriminologi sebagai "the body of knowledge regarding delinquency and crime as social phenomenon. It includes within its scope the process of making law, the breaking of laws, and reacting to word the breaking of laws ..." (Mulyadi, 2007), maka anak juga perlu dilihat sebagai bagian kriminologi, Menurut Lilik Mulyadi (2007) ada 
beberapa faktor yang mempengaruhi kejahatan oleh anak yaitu Pertama, pembuatan hukum yang dapat meliputi telaah konsep kejahatan, siapa pembuat hukum dengan faktor-faktor yang harus diperhatikan dalam pembuatan hukum. Kedua, pelanggaran hukum yang dapat meliputi siapa pelakunya, mengapa sampai terjadi pelanggaran hukum tersebut serta faktor-faktor yang mempengaruhinya. Ketiga, reaksi terhadap pelanggaran hukum melalui proses peradilan pidana dan reaksi masyarakat.

Adapun penelitian sebelumnya yang membahas tindak pidana anak dari perspektif penegak hukum yaitu penelitian yang mengulas mengenai lingkup mekanisme penuntutan terhadap tindak pidana anak yang dilakukan Jaksa Penuntut Umum Kejaksaan Negeri Semarang serta upaya yang ditempuh harus diusahakan dengan cara Diversi yang menjurus kekeluargaan, (Sulchan \& Ghani, 2017). Penelitian kedua mengulas mengenai proses jalannya perkara pidana terhadap anak nakal (J uvenile Delinquency) sesuai hukum acara pidana di wilayah hukum Kota Semarang (Maskur, 2012). Penelitan ketiga mengulas mengenai perlindungan hukum terhadap anak sebagai pelaku tindak pidana dalam kasus putusan No: 164/pid.b/2009/PN.PI dan mengulas mengenai kendala yang di alami penegak hukum dalam pemenuhan hak-hak tersangka (Saharuddin, 2014)

Penelitian selanjutnya yang terdapat dalam jurnal internasional mengulas tentang tanggungjawab pidana terhadap anak yang terjadi membuat anak menjadi tidak bebas dalam memilih. Penanganan
Anak dalam proses peradilan lebih banyak memberikan diskriminasi kepada anak (Elliott, 2003). Penelitian berikutnya mengulas mengenai pembagian pertanggungjawaban pidana kepada seseorang berdasarkan pada umur. Seorang hakim dalam memutus perkara harus melihat umur seseorang, jika itu adalah anak maka segera dipisahkan. Hal ini untuk pertimbangan perkembangan psikologis anak dan pengalamannya (McDiarmid, 2013).

Sementara penelitian yang dilakukan oleh peneliti saat ini bertolak dari kajian kriminologi sebagai salah satu ilmuyang menekankan terhadap kejahatan diharapkan penanganan yang dilakukan jaksa penuntut umum di Kota Semarang kedepannya akan lebih luas dalam melihat penyebab timbulnya kejahatan. Berdasarkan latarbelakangan di atas maka perlu dibahas lebih lanjut bagaiamana penyelesaian perkara perkara anak dalam perspektif jaksa penuntut umum di Kejaksaan Negeri Kota Semarang saat ini, dan bagaimana model penyelesaian perkara anak oleh penuntut umum di Kejaksaan Negeri Kota Semarang yang akan datang.

\section{B. METODE PENELITIAN}

Jenis penelitian adalah penelitian yuridis empiris dengan metode pendekatan dalam penelitian ini yang digunakan adalah pendekatan sociolegal. Pendekatan penelitian socio legal menempatkan hukum sebagai gejala sosial yang menitikberatkan perilaku individu atau masyarakat dalam kaitannya dengan hukum. Sehingga dalam penelitian semacam 
Jurnal Pembangunan Hukum Indonesia

Volume 2, Nomor 1, Tahun 2020
Program Studi Magister Ilmu Hukum Fakultas Hukum Universitas Diponegoro ini, hukum ditempatkan sebagai variabel terikat dan faktor-faktor non hukum yang mempengaruhi hukum dipandang sebagai variabel bebas. Pendekatan ini memberikan dampat yang besar terhadap perkembangan metodologi penelitian hukum, karena socio legal mengarahkan penelitiannya untuk fokus terhadap kajian empiris beserta yuridisnnya, yang pada akhrnya penelitian socio legal adalah untuk mencapai keadilan materiil bagi masyarakat (Paksi, 2016).

Sumber data dalam penelitian ini dibagi menjadi sumber data primer dan sekunder. Sumber data primer yaitu wawancara dengan Jaksa Pidana Umum Kejaksaan Negeri Kota Semarang. Sumber data sekunder yaitu Undang-Undang No. 11 Tahun 2012 Tentang Sistem Peradilan Pidana Anak dan perbandingan negara lain. Sedangkan analisis data dilakukan dengan mengumpulkan dan mengklasifikasi sesuai dengan permasalahan yang diteliti. Data yang diperoleh kemudian dianalisis untuk mencari kejelasan dari masalah yang dibahas.Dalam menganalisis data pada penelitian ini dipergunakan analisis data kualitatif terhadap data yang telah dikumpulkan (Moleong, 2008).

\section{HASIL DAN PEMBAHASAN}

\section{Penyelesaian Perkara Anak Dalam Perspektif} Jaksa Penuntut Umum Di Kejaksaan Negeri

\section{Kota Semarang Saat Ini}

Perlindungan anak merupakan tolak ukur peradaban masyarakat suatu bangsa, maka wajib diusahakan perlindungan anak demi kepentingan nusa dan bangsa.Kegiatan perlindungan anak merupakan suatu tindakan hukum oleh karena itu perlu jaminan hukum bagi kegiatan perlindungan anak tersebut.Kepastian hukum perlu diusahakan demi kelangsungan kegiatan perlindungan anak dan mencegah penyelewengan yang membawa akibat negatif yang tidak diinginkan dalam pelaksanaan kegiatan perlindungan anak.

Dalam konteks anak sebagai pelaku sebagai pelaku kejahatan, Maud A. Merril dalam (Cahyaningtyas, 2016) memberikan perumusan tentang juvenile delinquency, yaitu seorang anak digolongkan anak delinkuent apabila tampak adanya kecenderungan-kecenderungan anti sosial yang demikian memuncaknya sehingga yang berwajib terpaksa atau hendaknya mengambil tindakan terhadapnya, dalam arti menahannya atau mengasingkannya.

Definisi anak dalam Rule 2.2 (a) The Beijing Rules,

"A juvenile is a child or young person who, under the respective legal system, may be dealt with for an offence in a manner which is different from adult" 5 (Juvenile adalah anak atau remaja yang menurut sistem hukum yang berlaku, telah melakukan kejahatan yang perlakuannya harus berbeda dengan perlakuan terhadap orang dewasa).

Proses penanganan anak yang berhadapan dengan hukum erat kaitannya dengan penegakan hukum itu sendiri, dimana dalam Sistem Peradilan Pidana Anak (juvenile justice system). Menurut Barda Nawawi Arief (2006) Sistem Peradilan Pidana pada hakikatnya merupakan "sistem kekuasaan 
Jurnal Pembangunan Hukum Indonesia

Volume 2, Nomor 1, Tahun 2020
Program Studi Magister Ilmu Hukum Fakultas Hukum Universitas Diponegoro menegakkan hukum pidana" yang diwujudkan dalam 4 (empat) subsistem yaitu a) kekuasaan penyidikan (oleh Badan/Lembaga Penyidik); b) kekuasaan penuntutan (oleh Badan/Lembaga Penuntut Umum); c)kekuasaan mengadili dan menjatuhkan putusan/pidana (oleh Badan Pengadilan); dan d) kekuasaan pelaksanaan putusan pidana" (oleh Badan/Aparat Pelaksana/Eksekusi).

Berdasarkan kewenangan dari Keempat institusi pilar sistem peradilan pidana anak telah diatur dalam peraturan perundang-undangan tersendiri yaitu UU No.11 Tahun 2012 Tentang Sistem Peradilan Pidana Anak sebagai landasan yuridis bagi aparat penegak hukum dalam menjalankan tugas dan fungsinya. Kewenangan tersebut dilengkapi dengan hukum pidana material yang diatur dalam KUHP dan hukum pidana formal yang diatur dalam KUHAP (Purnomo, \& Gunarto, 2018)

Dalam proses penyidikan maka pelru hadirnya polisi sebagai stitusi formal ketikaanak nakal pertama kali bersentuhan dengan sistem peradilan, yang jugaakan menentukan apakah anak akan dibebaskan atau diproses lebih lanjut (Laksana, 2017) Penyidik yang melakukan penyidikan kasus anak adalah orang yang sudah berpengalaman sebagai penyidik; mempunyai minat, perhatian, dedikasi, dan memahami masalah Anak; dan telah mengikuti pelatihan teknis tentang peradilan Anak (Pasal 26 Ayat 3 UU No. 11 Tahun 2012 SPPA).

Dalam rangka penyidikan telah ada Ramburambu yang diberikan oleh Undang-Undang Nomor

\section{Tahun 2012 Tentang Sistem Peradilan Pidana} Anak, Pasal 8 Ayat (1) proses diversi dilakukan melalui musyawarah dengan melibatkan anak dan orang tua/walinya, korban dan/orang tua/walinya, pembimbing kemasyarakatan, dan pekerja sosial/professional.

Kewajiban melaksanakan Diversi mulai penyidikan dilaksanakan dalam hal tindak pidana yang dilakukan diancam dengan pidana penjara dibawah 7 (tujuh) tahun dan bukan merupakan pengulangan tindak pidana. Terhadap anak berhadapan dengan hukum ( $\mathrm{ABH}$ ) yang melakukan tindak pidana dengan ancaman di atas 7 (tujuh) tahun tidak wajib dilakukan Diversi namun tetap dilakukan dengan prinsip restorative dan kepentingan terbaik bagi anak. Hanya $\mathrm{ABH}$ saja bagi yang melakukan tindak pidana yang ancaman pidana 7 (tujuh) tahun ke atas dan merupakan pengulangan maka tidak dilakukan Diversi (Abdurrachman, 2016)

Proses diversi pada saat penyidikan dalam waktu paling lama 7 (tujuh) hari setelah penyidikan dimulai. Proses Diversi dilaksanakan paling lama 30 (tiga puluh) hari setelah dimulainya Diversi. Dalam hal melakukan pemeriksaan terhadap Anak Korban dan Anak Saksi, Penyidik wajib meminta laporan sosial dari Pekerja Sosial Profesional atau Tenaga Kesejahteraan Sosial setelah tindak pidana dilaporkan atau diadukan. Hasil Penelitian Kemasyarakatan wajib diserahkan oleh Bapas kepada Penyidik dalam waktu paling lama 3 × 24 (tiga kali dua puluh empat) jam setelah permintaan 
Jurnal Pembangunan Hukum Indonesia

Volume 2, Nomor 1, Tahun 2020
Program Studi Magister Ilmu Hukum Fakultas Hukum Universitas Diponegoro penyidik diterima (Pasal 27,28,29 UU No. 11 Tahun 2012 Tentang SPPA).

Dalam hal proses Diversi berhasil mencapai kesepakatan, Penyidik menyampaikan berita acara Diversi beserta Kesepakatan Diversi kepada ketua pengadilan negeri untuk dibuat penetapan. Dalam hal Diversi gagal, Penyidik wajib melanjutkan penyidikan dan melimpahkan perkara ke Penuntut Umum dengan melampirkan berita acara Diversi dan laporan penelitian kemasyarakatan.

Setelah gagal maka akan berlanjut pemerikasaanya oleh jaksa penuntut umum.Penuntutan terhadap perkara Anak dilakukan oleh Penuntut Umum yang ditetapkan berdasarkan Keputusan Jaksa Agung atau pejabat lain yang ditunjuk oleh Jaksa Agung. Syarat umum menjadi jaksa penuntut umum dalam menangani anak yaitu orang yang telah berpengalaman sebagai penuntut umum; mempunyai minat, perhatian, dedikasi, dan memahami masalah Anak; dan telah mengikuti pelatihan teknis tentang peradilan Anak (Pasal 41 UU No. 11 Tahun 2012 Tentang SPPA).

Berdasarkan hasil wawancara dengan Jaksa Penuntut Umum (JPU) Anak Meta Permatasari di Kejaksaan Negeri Kota Semarang (Wawancara,22 April 2019) mengatakan bahwa:

"Semua jaksa perempuan adalah jaksa penuntut umum anak dengan berdasarkan pada surat keputusan jaksa agung tentang penunjukan jaksa penuntut umum anak di Kejaksaan Negeri Kota Semarang. Para jaksa yang ditunjuk oleh Jaksa Agung nantinya berkewajiban menyelesaikan kasus anak sebagai pelaku, korban dan/atau saksi dalam suatu tindak pidana"

Meta Permatasari selaku Jaksa Penuntut Umum Anak juga mengatakan bahwa:

"Penyelesain dilakukan oleh jaksa penuntut umum sejak mendapat berkas dari penyidik dan kemudian melakukan pemeriksaan berkas dengan jangka waktu paling lama 7 (tujuh) hari.Bersamaan dengan pemeriksaan berkas Jaksa Penuntut Umum juga melakukan diversi untuk tindak pidana yang ancamannya dibawah 7 (tujuh) tahun dan bukan residivis (pengulangan)".

Berdasarkan hasil wawancara Meta

\section{Permatasari juga mengatakan bahwa:}

"Dalam proses diversi wajib menghadirkan orang tua pelaku dan korban serta Bapas. Apabila diversi gagal maka lanjut ke persidangan dengan pelimpahan terdakwa dan barang bukti ke Pengadilan.Bahwa selama tahun 2016-2018 jaksa penuntut umum anak di Kejaksaan Negeri Kota Semarang telah berhasil melakukan diversi pada dua kasus yaitu pencurian dan kekerasan terhadap anak. Sedangkan yang lainnya tidak bisa dilakuka karena hampir rata-rata adalah residivis dan ancamannya di atas 7 (tujuh) tahun"

Tabel. 1.2 Rata-Rata Penuntutan Terhadap Anak di Kejaksaan Negeri Kota Semarang Tahun 2016-2018

\begin{tabular}{|c|c|c|c|}
\hline Tahun & $\begin{array}{c}\text { Rata Rata } \\
\text { Penuntutan } \\
1 \text { bulan - } 12 \\
\text { bulan (1 } \\
\text { Tahun) }\end{array}$ & $\begin{array}{c}\text { Rata Rata } \\
\text { Penuntutan } \\
1 \text { Tahun - } 3 \\
\text { Tahun }\end{array}$ & $\begin{array}{c}\text { Rata Rata } \\
\text { Penuntut } \\
\text { an } 3 \\
\text { Tahun - } 6 \\
\text { Tahun } \\
\end{array}$ \\
\hline $\begin{array}{l}2016- \\
2018\end{array}$ & $\begin{array}{l}\text { a. } 6 \text { bulan } \\
\text { penjara } \\
\text { dan denda } \\
\text { Rp, } \\
1.000 .000 \\
\text { b. } 9 \text { bulan } \\
\text { penjara } \\
\text { dan denda } \\
\text { Rp.10.000 } \\
.001\end{array}$ & $\begin{array}{l}\text { a. } 1 \text { tahun } 3 \\
\text { bulan } \\
\text { penjara } \\
\text { b. } 1 \text { tahun } 6 \\
\text { bulan } \\
\text { c. } 1 \text { tahun } 8 \\
\text { bulan }\end{array}$ & $\begin{array}{l}6 \text { tahun } \\
\text { penjara }\end{array}$ \\
\hline
\end{tabular}




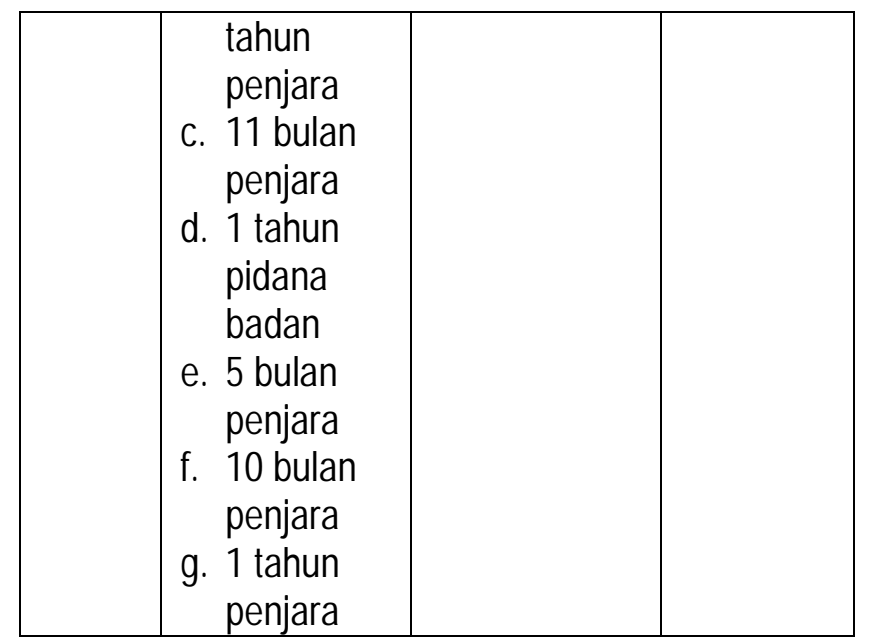

Sumberkejari.semarangkota.go.id Tahun 2016-2018

Adapun kategorisiasi kenakalan perbuatan yang telah dilakukan oleh anak. Kategori tersebut tujuannya untuk mengelompokkan kejahatan menjadi tiga (tiga) yaitu sebagai berikut a) kejahatan tingkat ringan,perbuatan yang tergolong pada tingkat kejahatan ringan adalah sebagai berikut pencurian ringan, penyerangan ringan tanpa menimbulkan luka, atau kerusakan ringan pada harta benda; b)kejahatan tingkat sedang,perbuatan yang tergolong pada tingkat kejahatan sedang adalah tipe kejahatan yang didalamnya terdapat kombinasi antara semua kondisi yang menjadi pertimbangan ketepatan untuk menyelesaiakannya apakah melalui diversi atau tidak; c) kejahatan tingkat berat, untuk kejahatan berat berat serperti kasus penyerangan seksual dan penyerangan fisik yang menimbulkan luka parah (Rahayu, 2015)

Adapun hambatan bagi jaksa penuntut umum selama melakukan penanganan perkara anak di Kejaksaan Negeri Kota Semarang. Apabila menggunakan teori Lawrence M. Friedman tentang sistem hukum yang meliputi sturktur hukum, subtansi hukum, dan budaya hukum (Nainggolan, \& Kalo, 2017), maka pemaparan hasil wawancara yang disampaikan oleh jaksa penuntut umum Meta Permatasari di atas dapat dlihat pada sistem hukum mana yang menjadi hambatan terlaksananya penyelesaian perkara anak:

a. Struktur hukum merujuk pada struktur institusiinstitusi penegakan hukum, seperti kepolisian, kejaksaan dan pengadilan. Mengacu dari sistem hukum ini terlihat adanya hambatan oleh jaksa penuntut umum dalam menyelesaikan perkara anak di Kota Semarang. Hal ini disebabkan waktu yang cukup singkat yang diberikan oleh UndangUndang Sistem Peradilan Anak dalam menyelesaikan perkara pada tahap penuntutan.

b. Substansi hukum adalah aturan, dan pola perilaku nyata manusia yang berada dalam sistem itu. Jadi substansi hukum menyangkut peraturan perundang-undangan yang berlaku yang memiliki kekuatan yang mengikat dan menjadi pedoman bagi aparat penegak hukum. Bertolak dari sistem hukum ini juga terlihat hambatan dari segi norma. Jangka waktu yang diberikan Undang-Undang dalam menyelesaikan perkara anak tidak mengekelompokan kapan batas waktu meneliti berkas dari penyidik, kapan batas waktu melakukan diversi, dan kapan menunggu hasil penelitian masyarakat dari badan permasyarakatan.

c. Budaya hukum menyangkut budaya hukum yang merupakan sikap manusia (termasuk budaya hukum aparat penegak hukumnya) terhadap 
Jurnal Pembangunan Hukum Indonesia

Volume 2, Nomor 1, Tahun 2020
Program Studi Magister Ilmu Hukum Fakultas Hukum Universitas Diponegoro hukum dan sistem hukum. Bertolak dari sistem hukum ini juga terlihat adanya hambatan terkait dengan sikap masyarakat yang lebih mengedepankan "ego" dari pada kemanfaatan dalam mencapai kesepakatan diversi. Akibat "ego" dari orang tua/wali korban maupun pelaku menimbulkan kerugian bagi anak, baik secara materiil maupun non materiil.

Berikut hasil wawancara (22 April 2019) dengan Jaksa Penuntut Umum Anak Meta Permatasari di Kejaksaan Negeri Kota Semarang yang mengatakan bahwa masih ditemukan beberapa hambatan yang di alami pada saat penanganan perkara anak di Kota Semarang:

a. "Pemenuhan syarat formil berupa penelitian masyarakat (Litmas) dari Balai Permasyarakatan (Bapas) seringkali mepet waktunya dengan habisnya masa penahanan. $\mathrm{Hal}$ ini mengakibatkan proses penanganan anak di Kejaksaan Negeri Semarang tidak dapat berjalan dengan maksimal"

b. "Pada saat pelaksaan diversi seringkali para orang tua atau wali dari pihak korban maupun pelaku tidak adanya kesepakatan untuk menyelesaikan kasus yang dilakukan oleh anaknya diluar sidang Pengadilan. Kedua orang tua/wali lebih mengedepankan "ego"-nya masingmasing akibatnya mengorbankan kepentingan anak.

c. "Masih sangat minim balai latihan kerja atau sejenis itu di Kota Semarang sehingga penerapan pengganti pidana denda terhadap anak pun seringkali tidak dapat dilaksanakan"

2. Model Penyelesaian Perkara Anak Oleh Penuntut Umum Di Kejaksaan Negeri

\section{Semarang Yang Akan Datang}

Dalam The Beijing Rules Rule 5.1,
"Sistem peradilan anak harus menekankan kesejahteraan remaja dan harus memastikan bahwa setiap reaksi terhadap pelanggar anak harus selalu sebanding dengan keadaan para pelaku dan pelanggaran".

\section{Dalam Aturan Komentar 5.1. Peraturan} Beijing, sistem Peradilan Anak adalah untuk: Sebuah Kesejahteraan Anak dan Prinsip proporsionalitas (Cahyaningtyas, 2018).

Penyelesaian kejahatan anak tidak dapat disamakan dengan perkara kejahatan yang dlakukan oleh orang dewasa.Faktor - faktor penyebab terjadi kejahatan anak juga perlu dilihat sebagai rangkain mengapa anak melakukan kejahatan.Dalam Teori Kriminologi seorang pelaku kejahatan haruslah dipandang dari dimensi yang luas.Kejahatan yang dimaksud disini adalah suatu tindakan yang dilakukan orang-orang dan atau instansi yang dilarang oleh suatu undang-undang (Silitonga, Ediwarman, \& dkk, 2017).

Adapun terdapat tiga titik pandang dalam melakukan analisis terhadap masalah kejahatan yaitu macrotheories adalah teori teori yang menjelaskan kejahatan dipandang dari segi struktur sosial dan dampaknya. Teori teori ini menitikberatkan rates of crime atau epidemiologi kejahatan daripada atas pelaku kejahatan, sebagai contoh teori anomi dan teori konflik. Sementara itu microtheories adalah teori yang menjelaskan mengapa seseorang atau kelompok orang dalam masyarakat melakukan kejahatan atau mengapa di dalam masyarakat terdapat orang-orang yang melakukan kejahatan dan mengatakan: 
Jurnal Pembangunan Hukum Indonesia

Volume 2, Nomor 1, Tahun 2020
Program Studi Magister IImu Hukum Fakultas Hukum Universitas Diponegoro terdapat pula sekelompok orang atau orang orang tertentu yang tidak melakukan kejahatan.

Teori ini menitikberatkan pada pendekatan psikologi atau sosiologis atau biologis., sebagai contoh teori kontrol dan social learning theory. Bridging theories adalah teori teori yang tidak atau sulit untuk dikategorikan kedalam, baik macrotheories maupun microtheories. Teori teori yang masuk kedalam kategori ini menjelaskan struktur sosial dan juga menjelaskan bagaimana seseorang atau kelompok orang menjadi penjahat. Sebagai contoh, teori subkultur dari teori differential opportunity (Erlina, 2014)

Bertolak dari teori kriminolog di atasi maka kejahatan anak tidak bisa pandang sebagai pelaku kejahatan secara utuh. Hal tersebut harus dilihat dengan siapa anak berteman, di mana lingkungan tempat anak bermain, seperti yang disampaikan dalam microtheories bahwa terdapat penjelasan mengapa anak melakukan kejahatan. Penjelasan ini harus di dengar oleh penegak hukum dan orang tua/ wali pelaku atau korban agar tidak menjustifikasi akan tetapi memahami kesalahan anak. Dengan penjelasan tersebut guna mempercepat proses penyelesaian anak tanpa harus melalui proses persidangan yang dapat mengakibatkan kerugian baik secara sosial atau secara psikis anak.

Melalui penyelesain dengan pendekatan restorative justice merupakan cara untuk mempertemukan dua kepentingan di luar persidangan. Adanya keterlibatan korban, pelaku dan masyarakat dalam mencari solusi perbaikan, rekonsiliasi, dan kepastian bersama. Ada banyak cara restorative justice dalam proses penyelesaian anak (Cahyaningtyas, 2018) :

a. Pengabdian masyarakat :Pengabdian masyarakat pertama kali diperkenalkan sebagai opsi hukuman di California pada 1960-an.Selama dua dekade berikutnya diperkenalkan di sebagian besar wilayah hukum barat melaluikeluar Amerika Serikat dan Kanada. Layanan masyarakat pertama kali tersedia di Inggrisdan Wales pada tahun 1973 dan di Skotlandia pada tahun 1977, di mana ia terbukti relatif populer sebagai opsi hukuman.

b. Mediasi dan reparasi korban-pelaku:Mediasi dan reparasi para korban berawal di Kitchener, Ontario dan di AustraliaGerakan Mennonite bertujuan untuk melibatkan para korban secara langsung dalam penyelesaian pelanggaran mereka.

Mediator yang terampil memfasilitasi pertukaran antara korban dan pelaku yang bertujuan menyediakanpenjelasan untuk pelanggaran, memungkinkan pelaku untuk menghargai dampak dari pelanggaran tersebutpada korban dan mencapai kesepakatan tentang tindakan yang akan diambil oleh pelaku untuk diperbaiki kerusakannya

c. Pertemuan Group Keluarga : Pertemuan group keluarga telah berupaya untuk melibatkan konstituensi yang lebih luas (termasuk 'pendukung'korban dan pelaku) dalam diskusi tentang pelanggaran dan pengambilan keputusantindakan yang harus dilakukan oleh pelaku untuk menebus kesalahan.

d. Sanksi lingkungan: sanski lingkungan didasarkan pada tradisionalsanksi dan proses penyembuhan komunitas. Sekelilingnya dapat mencakup, sebagai tambahan bagi pelaku dan korban,keluarga dan teman-teman dari keduanya, personil peradilan pidana dan layanan sosial, dan tertarikanggota komunitas. Secara bergiliran berbicara melalui 'bagian pembicaraan' yang simbolis, para anggotasekelilingnya berusaha untuk mendapatkan pemahaman tentang pelanggaran dan untuk mengidentifikasi bagaimana semua yang terkena dampakpihak 
dapat disembuhkan dan kejahatan lebih lanjut dicegah.

Pendekatan restorative justice kemudian di adopsi melalui penyelesaian diversi dengan tujuan:
a. Mencapai perdamaian antara korban dan anak
b. Menyelesaikan perkara anak diluar pengadilan
c. Menghindarkan anak dari perampasan kemerdekaan
d. Mendorong masyarakat untuk berpartisipasi; dan
e.Menanamkan rasa tanggungjawab kepada anak (Sepud, 2016)

Proses diversi pada saat penuntutan dilakukan musyawarah antara anak beserta orang tua atau walinya, korban beserta orang tua atau walinya, pembimbing masyarakat, dan pekerja sosial profesional. Proses ini dlakukan paling lama 7 hari setelah menerima berkas perkara dari penyidik (Yudaningsih, 2016)

Berdasarkan hambatan - hambatan yang di alami oleh jaksa penuntut umum anak di kejaksaan Negeri Kota Semarang perlu adanya sebuah model baru kedepannya yang menjadi mesin berjalannya penanganan anak diluar persidangan. Bertolak dari teori dan penyelesaian yang telah digunakan di berbagai negara pada umumnya dan Indonesia pada khususnya dapat dilihat bahwa model diversi yang digunakan selama ini sebenarnya hanya bersandar pada orang tua/wali pelaku dan korban dan hasil penelitian Badan Permasyarakatan.

Jika demikian model penyelesaian maka selamanya tidak akan muncul pemahaman yang berbasis pada keadilan anak, karena yang dikedepankan adalah unsur subjektivitas masingmasing orang tua/wali. Oleh karenanya penyelesain tersebut harus bergeser pada keterlibatan masyarakat secara langsung. Seperti yang diterangkan di dalam pendeketan restorative justice dengan cara pertemuan group keluarga atau family group conference.

Kemunculan family group conference (FGC) disebabkan situasi politik dan budaya tertentu yang ada di Selandia Baru pada saat itu. Kelompok keluargakonferensi berasal di Selandia Baru pada 1980-an. Penduduk asli Selandia Baru,orang-orang Maori, telah mengkritik pihak berwenang selama beberapa dekade. Mereka mengeluh bahwapendekatan pemerintah untuk menangani masalah sosial menggunakan metode Eropa (yaitu menggunakan keahlian untuk menyelesaikan konflik) tidak cocok dengan cara tradisional di mana Maori menyelesaikan konflik. Struktur semacam ini menghasilkan representasi berlebihan yang signifikan dari anak-anak Maori. Dalam komunitas Maori, penitipan anak dan pengasuhan anak adalah tanggung jawab seluruh keluarga besar; anggota keluarga inti, teman-teman dan orang-orang penting lainnya dalam kehidupan seorang anak (Havnen \& Christiansen, 2014)

Hal tersebut membuat pemerintah mensahkan Undang-undang baru di Selandia Baru pada tahun 1989 mengenai Anak-anak dan Orang Muda dan Undang-Undang Keluarga. Undang-undang tersebut membuat konferensi kelompok keluarga wajib untuk anak terlebih seriuskasus kesejahteraan, dan untuk kasus-kasus yang menangani kejahatan remaja yang serius. FGC saat ini banyak digunakannegara, 
meskipun dalam varian yang berbeda dan pada berbagai tingkat implementasi.

Adapun 4 (empat) model yang digunakan dalam FGC (Cunning \& Bartlett, 2006):

a. Tim Proyek dikelola oleh 1 koordinator proyek yang bekerja penuh, 1 bekerja penuh koordinator konferensi dan 9 koordinator paruh waktu yang dikontrak dari beragam, budaya, pengaturan komunitas, 4 di antaranya diperbantukan dari lembaga mitra. Selain itu supervisi sehari-hari dari Koordinator Proyek, pengawasan bersama secara simultan tersedia konsultasi dari pengawas kesehatan mental dan kesejahteraan anak koordinator setiap bulan. Pengawas ini berasal dari agen mitra dan berfungsi sebagai anggota Kelompok Kerja dan Komite Pengarah.

b. Kelompok Kerja terdiri dari Koordinator Proyek, satu wakil dari masing-masing dari lembaga mitra, dan Direktur Penelitian. Kelompok Kerja bertanggung jawab untuk mengembangkan rekomendasi mengenai kebijakan dan prosedur dan tersedia untuk pembekalan setelah konferensi keluarga dan merupakan bagian dari dan bertanggung jawab kepada Komite Pengarah.

c. Komite Pengarah terdiri dari Kelompok Kerja serta direktur I cabang manajer masing-masing lembaga mitra. Bertanggung jawab untuk membuat keputusan terkait untuk kebijakan dan prosedur, untuk penunjukan staf, dan untuk penggalangan dana dan keuangan manajemen proyek.

d. Penelitian dan evaluasi adalah aspek kunci dari FGC. Tim Proyek, Kelompok Kerja, dan Komite Pengarah berkontribusi secara spesifik untuk mendefinisikan dan mengukur hasil proyek. Pusat Anak dan Keluarga, bekerja sama dengan peneliti di Lembaga Bantuan Anak-Anak Katolik, Lembaga Bantuan Anak-anak Toronto, dan Universitas, berpartisipasi dalam penelitian ini tentang efektivitas jangka panjang FGC.

Salah satu cara untuk mempromosikan suara keluarga dalam kesejahteraan anak adalah dengan menggunakan konferensi kelompok keluarga. "Kelompok keluarga" terdiri dari anggota keluarga beserta kerabat, teman, dan dukungan dekat lainnya, dan "konferensi" mengacu pada mengadakan forum pengambilan keputusan untuk menyelesaikan bidang yang menjadi perhatian. Proses keadilan restoratif ini sekarang diterapkan dalam kesejahteraan anak dan juga arena lainnya termasuk sekolah, keadilan pemuda, dan layanan orang dewasa di banyak negara dan budaya (Pennell, 2004)

Dengan menggunakan cara pertemuan group keluarga atau family group conference para pihak baik korban atau pelaku akan lebih objektif dalam melihat kasus kejahatan anak sebab akan hadir kedua keluarga sedarah maupun orang lain yang mengetahui kasus tersebut. Pada saat conference tersebut berlangsung akan dibahas kasus tersebut dan akan diputuskan juga sanksi apa yang harus diberikan. Posisi jaksa penuntut umum dan Badan Permasyarakatan hanya sebagai pengelola conference sedangkan yang mediatornya adalah orang yang ditokohkan dari kedua keluarga tersebut.

Model pertemuan group keluarga atau family group conference dapat berlangsung jika dimasukan dalam norma sistem peradilan anak dan dapat berlangsung juga jika memperpanjang jangka waktu pemeriksaan perkara anak pada saat penuntutan agar proses diversi dapat berjalan maksimal. Hal tersebut diperlukan tidak lain dan tidak bukan untuk kepentingan anak sebagai penerus bangsa.

\section{SIMPULAN}

Perspektif jaksa penuntut di Kejaksaan Negeri Kota Semarang dalam penyelesaian perkara anak 
Jurnal Pembangunan Hukum Indonesia

Volume 2, Nomor 1, Tahun 2020
Program Studi Magister Ilmu Hukum Fakultas Hukum Universitas Diponegoro saat ini masih belum maksimal. Hal tersebut dapat dilihat dari banyak kasus yang dituntut selama tahun 2016 sampai dengan 2018. Hampir semua perkara yang dituntut merupakan perkara residivis (pengulangan) dan perkara yang ancaman pidananya di atas 7 (tujuh) tahun. Upaya untuk mengedepankan kepentingan anak telah dilakukan selama tiga tahun kebelakang melalui diversi akan tetapi yang berhasil hanyalah dua perkara yaitu pencurian dan kekerasan terhadap anak. Berbagai hambatan dialami oleh jaksa penuntut umum baik dari aspek struktur hukum, subtansi hukum, dan budaya hukum.

Pertama, pada level struktur hukum dapat dilihat tidak adanya koordinasi antara jaksa penuntut umum dengan bapas, sementara waktu yang ditentukan oleh Undang-Undang hanyalah 7 (tujuh) hari akibatnya pemeriksaan dan upaya diversi dilakukan secara tergesa-gesa. Kedua, pada level subtansi dapat dilihat pada norma yang ada saat ini tidak diberikan batasan waktu antara pengerjaan pemeriksaan berkas oleh jaksa penuntut umum, penelitian masyarakat oleh Bapas, dan Upaya diversi. Ketiga, pekerjaan tersebut dilakukan secara bersamaan dalam jangka waktu 7 (tujuh) hari sehingga proses pemeriksaan tidak dapat maksimal. Dan yang terakhir pada level budaya hukum masih terlihat adanya "ego" pada saat proses diversi dilakukan. Baik orang tua/wali korban maupun pelaku bersikeras dan lebih memilih jalur persidangan, sementara jalur tersebut sangat merugikan kepentingan anak.
Model penyelesaian perkara anak oleh Jaksa Penuntut Umum di Kejaksaan Negeri Kota Semarang yang akan datang perlu adanya pergeseran dari yang sebelumnya banyak melibatkan orang tua/wali kedua belah pihak seperti yang diatur dalam UU No. 11 Tahun 2012 Tentang sistem peradilan anak harus ditambahkan pihak keluarga dan masyarakat yang mengetahui kasus itu atau masyarakat setempat. Model ini disebut pertemuan group keluarga atau family group conference, melalui model tersebut diharapkan potensi berhasilnya diversi akan lebih besar karena keputusan berdasarkan tiap-tiap masyarakat atau keluarga yang hadir, posisi jaksa dan badan permasyarakatan hanya sebagai pengelola dan mediator family group conference adalah tokoh yang ditunjuk oleh keduanya. Model ini dapat terlaksana jika diperpanjang jangka waktu pemeriksaan pada tahap penuntutan aga proses diversi dapat berjalan dengan maksimal.

\section{DAFTAR PUSTAKA}

\section{BUKU}

Arief, Barda N. (2006). Kapita Selekta Hukum Pidana Tentang Sistem Peradilan Pidana Terpadu. Semarang: Badan Penerbit Universitas Diponegoro.

Cunning, Sandra., \& Bartlett, Diane. (2006). Family Group Conferencing: Assessing The LongTerm Effectiveness of An Alternative Approach In Child Protection. Toronto: The George Hull Centre For Children and Familly . 
Dewi, D. (2011). Mediasi Penal: Penerapan Restorative Justice Di Pengadilan Anak di Indonesia. Depok: Indie Publishing .

Havnen, Karen J Skaale., \& Christiansen, Oivin. (2014). Knowledge Review On Family Group Conferencing, Experience And Outcome. Bergen: Uni Research Health .

Moleong, Lexy J. (2008). Metodologi Penelitian

Kualitatif. Bandung: Remaja Rosdakarya Offset.

Mulyadi, L. (2007). Kapita Selekta Hukum Pidana,

Kriminologi dan Victimologi. Jakarta: PT.

Djambatan

Paksi, T. F. (2016). "Merefleksi Pendekatan Sosio-

Legal Dalam Penelitian Hukum" dalam Penelitian Hukum Interdisipliner . Yogyakarta: Thafa Media .

Priyatno, D. (2009). Sistem Pelaksanaan Pidana Penjara Di Indonesia. Bandung: Refika Aditama .

\section{JURNAL}

Abdurrachman, H. (2016). Negara Hukum dan Ide Restoratif Justice dalam Penanganan Terhadap Anak Yang Berhadapan dengan Hukum dalam Proses Penyidikan Berdasarkan Undang-Undang No. 11 Tahun 2012 Tentang Sistem Peradilan Anak. Seminar Nasional Hukum Universitas Negeri Semarang, Vol.2, (No.1), pp. 234-235.
Cahyaningtyas, I. (2016). Perlindungan Anak Di Lembaga Pembinaan Khusus Anak Dalam Perspektif Model Pembinaan Anak Secara Perseorangan. Legality, Vol.24, (No.1),p.31.

Cahyaningtyas, I. (2018). Penal Mediation of Treatments For Children In The Juvenile Justice System. Diponegoro Law Review, Vol.3, (No.2), pp. 267-269

Elliott, C. (2003). Criminal Responsibility and Children: A New Defence Required to Acknowledge the Absence of Capacity and Choice. The J ournal of Criminal Law, Vol.75, p. 308.

Erlina. (2014). Analisa Kriminologi Terhadap Kekerasan Dalam Kejahatan. Addaulah, Vol.3, (No.2), p.223.

Laksana, Andry W. (2017). Keadilan Restoratif Dalam Penyelesaian Perkara Anak Yang Berhadapan Dengan Hukum Dalam Sistem Peradilan Pidana Anak. Pembaharuan Hukum, Vol.4, (No.1), p.58.

Maskur, Muhammad A. (2012). Perlindungan Hukum Terhadap Anak Nakal (Juvenile Delinquency) Dalam Proses Acara Pidana Indonesia. Pandecta, Vol.7, (No.2), p.172.

McDiarmid, C. (2013). An Age of Complexity: Children and Criminal Responsibility in Law. Youth J ustice, Vol. 13, (No.2), pp.1-2.

Nainggolan, Secsio Jimec., \& Kalo, Syafrudin. (2017). Analisis Yuridis Penentuan Kedudukan Saksi Pelaku Sebagai Justice Collaborator Dalam Tindak Pidana Narkotika 
Jurnal Pembangunan Hukum Indonesia

Volume 2, Nomor 1, Tahun 2020
Program Studi Magister Ilmu Hukum Fakultas Hukum Universitas Diponegoro
Di Pengadilan Negeri Siantar (Studi Putusan No. 231/Pid.Sus/2015/PN). Usu Law J ournal, Vol.5, (No.3), p.109.

Pennell, J. (2004). Family Group Conferencing In Child Welfare: Responsive and Regulatory interfaces. Sociology \& Social Welfare, Vol.31, (No.1), pp.120-121.

Purnomo, Bambang., \& Gunarto. (2018). Penegakan Hukum Tindak Pidana Anak Sebagai Pelaku Dalam Sistem Peradilan Anak (Studi Kasus Di Polres Tegal). Hukum Khaira Ummah, Vol.13, (No.1), p.49.

Rahayu, S. (2015). Diversi Sebagai Alternatif Penyelesaian Perkara Tindak Pidana Yang Dilakukan Anak Dalam Perspektif Sistem Peradilan Anak . Jurnal Ilmu Hukum Jambi, Vol.6, (No.1), p.134.

Saharuddin. (2014). Perlindungan Hukum Terhadap Anak Sebagai Pelaku Tindak Pidana Pembunuhan ( Studi Kasus Putusan No: 164/Pid.B/2009/PN.PL). IImu Hukum Legal Opinion, Vol.2, (No.6), p.3.

Sepud, I. M. (2016). Alternatif Penyelesaian Tindak Pidana Narkotika Anak Melalui Diversi. Hukum Prioris, Vol.5, (No.3), p.289.

Silitonga, Marihot Tua., Ediwarman, \& dkk. (2017). Analisis Hukum Mengenai Sanksi Pidana Penjara Seumur Hidup Terhadap Pelaku Tindak Pidana Pembunuhan Berencana Dalam Perspektif Krimonologi: Studi Pengadilan Negeri Medan. Usu Law Journal, Vol.5, (No.3), p.67.
Sodiqin, A. (2015). Restorative Justice Dalam Tindak Pidanan Pembunuhan: Perspektif Hukum Pidana Indonesia dan Hukum Pidana Islam. Asy-Syir'ah, Vol.49, (No.1), p.75.

Sulchan, Achmad., \& Ghani, Muchamad Gibson. (2017). Mekanisme Penuntutan Jaksa Penuntut Umum Terhadap Tindak Pidana Anak. Ulul Albab: Studi dan Penelitian Hukum Islam, Vol.1, (No.1), p.114.

Warsito, D. S. (2018 ). Sistem Pemidanan Terhadap Pelaku Tindak Pidana Penyalahgunaan Narkotika . Daulat Hukum, Vol.1, (No.1), p.38.

Yudaningsih, L. P. (2016). Tahap-Tahap Diversi Terhadap Anak Sebagai Pelaku Tindak Pidana (Anak Yang Berkonflik Dengan Hukum) Di Wilayah Hukum Pengadilan Negeri Jambi. Ilmu Hukum, Vol.7, (No.2), p.74. 